\title{
Investigation of tick-borne bacteria (Rickettsia spp., Anaplasma spp., Ehrlichia spp. and Borrelia spp.) in ticks collected from Andean tapirs, cattle and vegetation from a protected area in Ecuador
}

\author{
Cristina Pesquera, Aránzazu Portillo, Ana M Palomar and José A Oteo*
}

\begin{abstract}
Background: Ixodid ticks play an important role in the transmission and ecology of infectious diseases. Information about the circulation of tick-borne bacteria in ticks is lacking in Ecuador. Our aims were to investigate the tick species that parasitize Andean tapirs and cattle, and those present in the vegetation from the buffer zone of the Antisana Ecological Reserve and Cayambe-Coca National Park (Ecuador), and to investigate the presence of tick-borne bacteria.
\end{abstract}

Methods: Tick species were identified based on morphologic and genetic criteria. Detection of tick-borne bacteria belonging to Rickettsia, Anaplasma, Ehrlichia and Borrelia genera was performed by PCRs.

Results: Our ticks included 91 Amblyomma multipunctum, 4 Amblyomma spp., 60 Rhipicephalus microplus, 5 Ixodes spp. and 1 Ixodes boliviensis. A potential Candidatus Rickettsia species closest to Rickettsia monacensis and Rickettsia tamurae (designated Rickettsia sp. 12G1) was detected in 3 R. microplus (3/57, 5.3\%). In addition, Anaplasma spp., assigned at least to Anaplasma phagocytophilum (or closely related genotypes) and Anaplasma marginale, were found in 2 A. multipunctum $(2 / 87,2.3 \%)$ and 13 R. microplus (13/57, 22.8\%).

Conclusions: This is the first description of Rickettsia sp. in ticks from Ecuador, and the analyses of sequences suggest the presence of a potential novel Rickettsia species. Ecuadorian ticks from Andear tapirs, cattle and vegetation belonging to Amblyomma and Rhipicephalus genera were infected with Anaplasmataceae. Ehrlichia spp. and Borrelia burgdorferi sensu lato were not found in any ticks.

Keywords: Ticks, Amblyomma multipunctum, Amblyomma scalpturatum, Amblyomma sp., Rhipicephalus microplus, Ixodes lasallei, Ixodes boliviensis, Ixodes sp., Rickettsia, Anaplasma, Ehrlichia, Borrelia, Ecuador

\section{Background}

Hard ticks (Ixodidae) are arthropods that suck blood from their vertebrate hosts and play an important role in the transmission and ecology of infectious diseases [1]. At least 30 ixodid tick species belonging to Amblyomma, Dermacentor, Haemaphysalis, Ixodes and Rhipicephalus genera have been documented in Ecuador [2]. These genera are recognized vectors of pathogenic bacteria

\footnotetext{
*Correspondence: jaoteo@riojasalud.es

Departamento de Enfermedades Infecciosas, Hospital San Pedro- Centro de Investigación Biomédica de La Rioja (CIBIR), C/ Piqueras 98, 26006 - Logroño, La Rioja, Spain
}

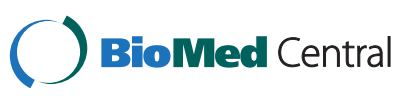

with medical and veterinary relevance in neotropical regions [3].

In South America, information about the occurrence of tick-borne bacteria in wild mammals, which are frequently exposed to tick-bites, is limited [4,5]. Moreover, several severe and economically important diseases of livestock in tropical regions are caused by tick-borne pathogens (i.e. bovine anaplasmosis caused by Anaplasma marginale) that can also infect wildlife species [6].

In Ecuador, the Andean tapir (Tapirus pinchaque) is listed as endangered species. Cattle introduction into the Andean tapir refuges (i.e. Cayambe-Coca Ecological Reserve) is negatively affecting tapir populations due to loss of habitat. In 
this environment, pathogens of domestic animals may threaten health of wild animals and vice versa [7].

It is known that Amblyomma scalpturatum, Amblyomma latepunctatum, Amblyomma multipunctum and Amblyomma ovale tick species infest the Andean tapir in Ecuador [7]. All but A. multipunctum have been found biting humans in South America, and harboring tickborne microorganisms [8-11]. The knowledge of bacteria transmitted by ticks (potential vectors and reservoirs of microorganisms) in a given area is useful for assessing the risk of infection in humans and animals. Therefore, the aims of our study were: 1 - To investigate which tick species parasitize the Andean tapirs and cattle, and those present in the vegetation from the buffer zone of the Antisana Ecological Reserve and Cayambe-Coca National Park in Ecuador, and 2.- To detect and to identify tick-borne bacteria belonging to Rickettsia spp., Anaplasma spp., Ehrlichia spp. and Borrelia spp. genera in the collected tick specimens.

\section{Methods}

From May to October 2011 and during February 2012, an investigation was conducted in the buffer zone of the Antisana Ecological Reserve and Cayambe-Coca National Park, Napo Province, Ecuador (Figure 1). This area is located in the basin of the Papallacta River, where 'The Andean tapir conservation project' was developing.

Ticks were removed from 6 Andean tapirs, cattle [13 cows (Bos taurus) from 4 farms] and vegetation (10 transects of 2-Km long that were toured twice). Arthropods were kept in tubes with ethanol recording the host/sampling and date, and sent to the Center of Rickettsioses and Arthropod-Borne Diseases, located at the Center of Biomedical Research from La Rioja (CIBIR), Logroño (Spain) for further analysis.

The species were identified based on morphologic criteria following taxonomic keys from the Neotropical region $[3,12,13]$. DNA was individually extracted using DNeasy Blood \& Tissue kit (Qiagen, Hilden, Germany).

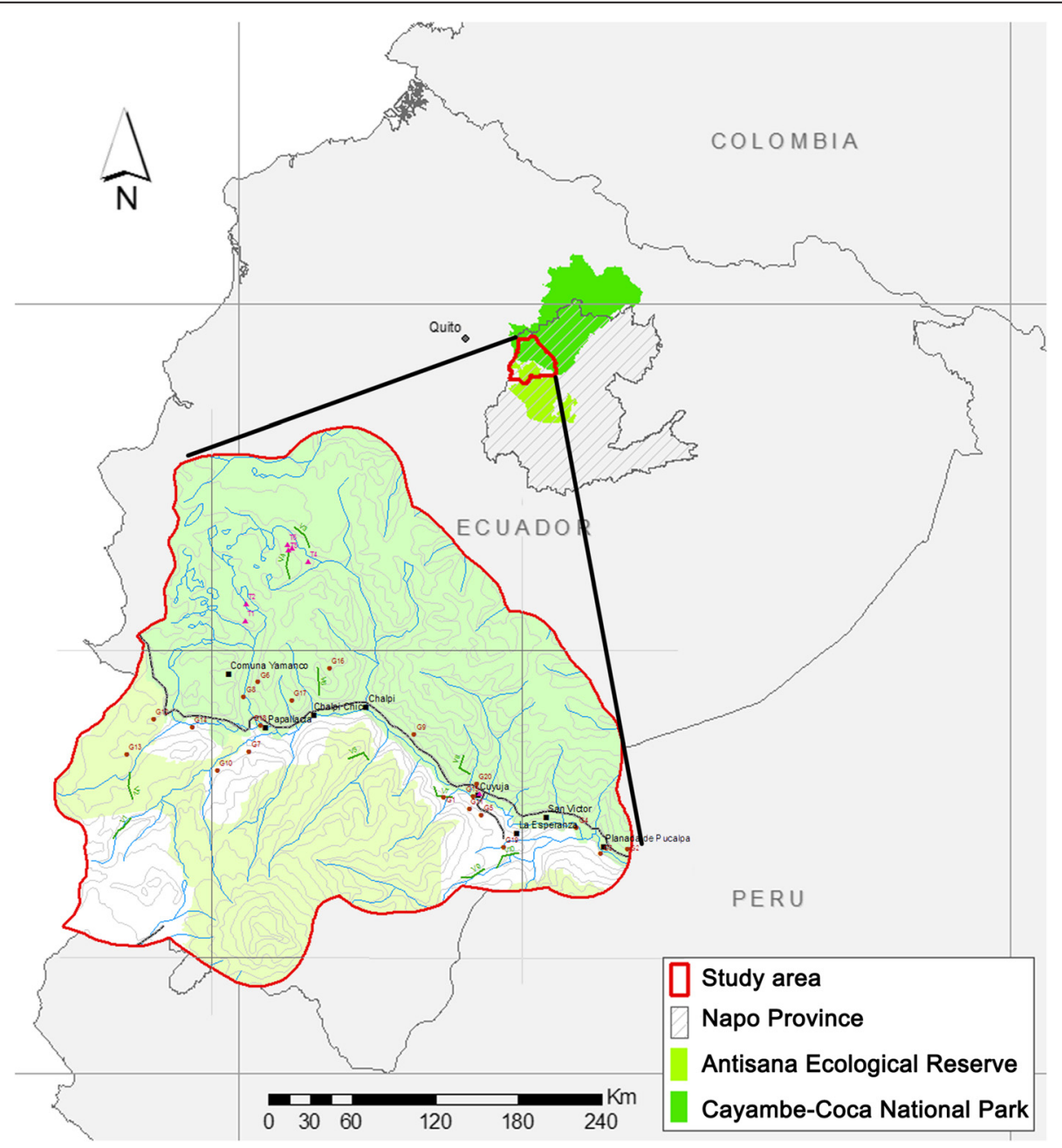

Figure 1 Study area in Ecuador (vector layers courtesy of EcoCiencia Foundation). 
Table 1 PCR primer pairs used in this study

\begin{tabular}{|c|c|c|c|c|c|c|}
\hline & Target gene & $\begin{array}{l}\text { Primer } \\
\text { name }\end{array}$ & Primer sequence $\left(5^{\prime} \rightarrow 3^{\prime}\right)$ & $\begin{array}{l}\text { Fragment } \\
\text { size (bp) }\end{array}$ & $\operatorname{Tm}\left({ }^{\circ} \mathrm{C}\right)$ & Reference \\
\hline \multirow[t]{6}{*}{ Tick species } & \multirow[t]{2}{*}{$16 \mathrm{~S}$ rRNA } & $16 S+1$ & CTGCTCAATGATIIITTAAATTGCTGTGG & \multirow[t]{2}{*}{456} & 48 & \multirow[t]{2}{*}{ [14] } \\
\hline & & $16 S-1$ & CCGGTCTGAACTCAGATCAAGT & & 54 & \\
\hline & \multirow[t]{2}{*}{$12 \mathrm{~S}$ rRNA } & $\mathrm{T} 1 \mathrm{~B}$ & AAACTAGGATTAGATACCCT & \multirow[t]{2}{*}{338} & 51 & \multirow[t]{2}{*}{ [15] } \\
\hline & & $\mathrm{T} 2 \mathrm{~A}$ & AATGAGAGCGACGGGCGATGT & & 53 & \\
\hline & \multirow[t]{2}{*}{ ITS2 } & RIB-4 F & CCATCGATGTGAAYTGCAGGACA & \multirow[t]{2}{*}{800} & \multirow[t]{2}{*}{55} & \multirow[t]{2}{*}{ [16] } \\
\hline & & RIB-R & GTGAATTCTATGCTTAAATTCAGGGGGT & & & \\
\hline \multirow[t]{2}{*}{ Pan- bacterial } & \multirow[t]{2}{*}{$16 \mathrm{~S}$ rRNA } & fD1 & AGAGTITGATCCTGGCTCAG & \multirow[t]{2}{*}{1500} & \multirow[t]{2}{*}{60} & \multirow[t]{2}{*}{ [17] } \\
\hline & & rP2 & ACGGCTACCTTGTTACGACTT & & & \\
\hline \multirow[t]{18}{*}{ Rickettsia spp. } & \multirow[t]{2}{*}{$g / t A$} & RpCS.877p & GGGGGCCTGCTCACGGCGG & \multirow[t]{2}{*}{1019} & \multirow[t]{2}{*}{65} & \multirow[t]{2}{*}{ [18] } \\
\hline & & RpCS1258n & ATTGCAAAAAGTACAGTGAACA & & & \\
\hline & \multirow[t]{2}{*}{ gltA (5' end) } & CS-78 & GCAAGTATCGGTGAGGATGTAAT GCTTCC & \multirow[t]{2}{*}{401} & \multirow[t]{2}{*}{48} & \multirow[t]{2}{*}[19]{} \\
\hline & & CS-323 & & & & \\
\hline & ompA & $\operatorname{Rr} 190.70 p$ & ATGGCGAATATTTCTCCAAAA & 631 & 46 & {$[20]$} \\
\hline & & $\operatorname{Rr} 190.701 n$ & GTTCCGTTAATGGCAGCATCT & & & \\
\hline & & $\operatorname{Rr} 190.70 p$ & ATGGCGAATATTTCTCCAAAA & 532 & 48 & {$[21]$} \\
\hline & & $\operatorname{Rr} 190.602 n$ & AGTGCAGCATTCGCTCCCCCT & & & \\
\hline & ompB (nested) & rompB OF & GTAACCGGAAGTAATCGTTTCGTAA & 511 & 54 & {$[22]$} \\
\hline & & rompB OR & GCTITATAACCAGCTAAACCACC & & & \\
\hline & & rompB SFG IF & GTTTAATACGTGCTGCTAACCAA & 420 & 56 & \\
\hline & & rompB SFG/TG IR & GGTTTGGCCCATATACCATAAG & & & \\
\hline & sca4 & D1f & ATGAGTAAAGACGGTAACCT & 928 & 50 & {$[23]$} \\
\hline & & D928r & AAGCTATTGCGTCATCTCCG & & & \\
\hline & $16 \mathrm{~S}$ rRNA & fD1 & AGAGTTGATCCTGGCTCAG & 426 & 59 & {$[17,24]$} \\
\hline & & Rc16S.452n & AACGTCATTATCTTCCTTGC & & & \\
\hline & $17 \mathrm{kDa}$ & 17 kDa-1 & GCTCTTGCAACTTCTATGTT & 434 & 58 & {$[25]$} \\
\hline & & 17 kDa-2 & CATTGTTCGTCAGGTTGGCA & & & \\
\hline Anaplasmal & msp2 & msp3F & CCAGCGTTTAGCAAGATAAGAG & 334 & 56 & {$[26]$} \\
\hline & & msp3R & GCCCAGTAACAACATCATAAGC & & & \\
\hline & 16S rRNA (nested) & ge3a & CACATGCAAGTCGAACGGATTATTC & 932 & 55 & {$[27]$} \\
\hline & & ge10r & TTCCGTTAAGAAGGAT CTAATCTCC & & & \\
\hline & & gegf & AACGGATTATTCTTTATAGCTTGCT & 546 & 55 & \\
\hline & & ge2 & GGCAGTATTAAAAGCAGCTCCAGG & & & \\
\hline & 165 rRNA & EHR 16SD & GGTACCYACAGAAGAAGTCC & 345 & 55 & {$[28]$} \\
\hline & EHR & EHR 16SR & TAGCACTCATCGTTTACAGC & & & \\
\hline & $16 \mathrm{~S}$ rRNA & GEP-s & CTGGCGGCAAGCYTAACACATGCAAGTCGAACGGA & 431 & 66 & {$[29]$} \\
\hline & GEP & GEP-as & CTTCTRTRGGTACCGTCATTATCTTCCCYAYTG & & & \\
\hline Borrelia spp. & flaB (nested) & Outer 1 & AARGAATTGGCAGTTCAATC & 497 & 52 & {$[30]$} \\
\hline & & Outer 2 & GCATTITCWATTITAGCAAGTGATG & & & \\
\hline & & Inner 1 & ACATATTCAGATGCAGACAGAGGTTCTA & 389 & 55 & \\
\hline & & Inner 2 & GAAGGTGCTGTAGCAGGTGCTGGCTGT & & & \\
\hline & & $23 \mathrm{SC} 1$ & TAAGCTGACTAATACTAATTACCC & 380 & 52 & {$[31]$} \\
\hline
\end{tabular}


Table 1 PCR primer pairs used in this study (Continued)

\begin{tabular}{llll}
\hline 5S-23S intergenic & 23SN1 & ACCATAGACTCTTATTACTTTGAC & \\
spacer (nested) & 5SCB & GAGAGTAGGTTATTGCCAGGG & 226 \\
& 23SN2 & ACCATAGACTCTTATTACTTTGACCA & \\
\hline
\end{tabular}

bp: base pairs; Tm: melting temperature; $\mathrm{Y}=\mathrm{C} / \mathrm{T} ; \mathrm{R}=\mathrm{A} / \mathrm{G} ; \mathrm{W}=\mathrm{A} / \mathrm{T}$.

Each tick specimen was screened by PCR for both identification of tick species and detection of bacteria including Rickettsia spp., Anaplasma spp., Ehrlichia spp. and Borrelia burgdorferi sensu lato (s. 1.). Tick species were confirmed by PCR targeting the tick mitochondrial $16 \mathrm{~S}$ ribosomal RNA (rRNA) [14]. PCR assays for the tick mitochondrial $12 \mathrm{~S}$ rRNA gene and the tick nuclear 5.8S-28S rRNA intergenic transcribed spacer 2 (ITS2) were also performed for selected samples $[15,16]$. For the screening of tick-borne bacteria, at least two fragment genes of each genus were tested by PCR assays. The molecular biomarkers selected to identify ticks are among the ones most widely used for the phylogenetics of ticks, being suitable to distinguish between closely related species. Biomarkers for the detection of microorganisms were selected based on our own expertise and according to previously reported usefulness and sensitivity. Target genes, specific primers and PCR conditions are listed in Table 1. Two negative controls, one of them containing water instead of template DNA and the other with template DNA but without primers, as well as positive controls of Rickettsia slovaca strain S14ab DNA (obtained from Vero cells inoculated in our facility with a Dermacentor marginatus tick from La Rioja, and known to be infected with $R$. slovaca), Anaplasma phagocytophilum strain Webster DNA kindly provided by Dr. Raoult (Unité de Recherche sur les Maladies Infectieuses et Tropicales Emergentes, France) and Dr. Dumler (The Johns Hopkins Hospital, USA), or Borrelia burgdorferi sensu stricto DNA kindly provided by Dr. Fingerle (German National Reference Centre for Borrelia, Germany) were included in all PCR assays. PCR products were sequenced in both directions. Sequences were compared with those available in the NCBI database using BLAST.

\section{Results}

\section{Identification of ticks}

A total of 161 ticks (75 removed from Andean tapirs, 66 from cattle and 20 collected over vegetation) were included in the study. Ten specimens (one of each stage and gender in case of adult ticks) were deposited in the Museum of Zoology of Pontificia Universidad Católica from Ecuador.

Morphologically, 84 specimens (12 nymphs, 47 male and 25 female ticks) corresponded to A. multipunctum, 4 specimens to A. scalpturatum and 7 were classified as
Amblyomma spp. For all but 4 specimens, the mitochondrial $16 \mathrm{~S}$ rRNA sequences (409 bp) were identical to the 16S rRNA gene from $A$. multipunctum (GenBank accession no. KC677673), or differed by $0.2-1.7 \%$ (1-7 bp) when compared to this species. No $12 \mathrm{~S}$ rRNA sequence from A. multipunctum was available in GenBank. Therefore, ours (from a specimen whose 16S rRNA sequence was identical to A. multipunctum KC677673) was deposited in GenBank under no. KM077433. It differed in sequence by $10 \%$ when compared to those available, and showed the highest identity (90\%) with the $12 \mathrm{~S}$ rRNA gene from Amblyomma sp. (GenBank accession no. AY342251). For the 4 tick specimens morphologically classified as $A$. scalpturatum, sequences of the $16 \mathrm{~S}$ rRNA showed maximum identity (90\%; 370/410 bp) with $A$. multipunctum, whereas $12 \mathrm{~S}$ rRNA and ITS2 sequences were closest to Amblyomma varium (90.6\% identity; $309 / 341$ bp and $93.6 \%$ identity; $836 / 893$ bp, respectively). Obtained sequences showed lower percentages of identity when compared to those from $A$. scalpturatum: $87 \%$ for $12 \mathrm{~S}$ rRNA (GenBank accession no. AY342276), and 90\% for ITS2 (GenBank accession no. AY619574). Therefore, these 4 ticks were classified as Amblyomma spp. and these three fragment genes were deposited in GenBank under nos. KM077434-6.

A total of 60 specimens were morphologically classified as Rhipicephalus microplus (formerly, Boophilus microplus) (6 nymphs, 16 male and 38 female ticks). In all these cases, the $16 \mathrm{~S}$ rRNA sequences were identical to the $16 \mathrm{~S}$ rRNA gene from $R$. microplus (GenBank accession no. EU918187).

According to morphological features, 5 female ticks were classified as Ixodes lasallei. The 16S rRNA sequences did not match with those from I. lasallei (GenBank accession no. AF549850) but were closest to this tick species (90\% identity). Due to this discrepancy, they were classified as Ixodes spp. and deposited in GenBank under no. KM077438.

Lastly, one specimen morphologically corresponded to Ixodes boliviensis. The $16 \mathrm{~S}$ rRNA sequences showed the highest identity (94\%) with the 16S rRNA gene from Ixodes sp. (GenBank accession no. KF702351). It was deposited in GenBank since no sequences for I. boliviensis were available (KM077437).

According to morphological and genetic classifications, our ticks included 91 A. multipunctum, 4 Amblyomma 
Table 2 Ticks included in this study

\begin{tabular}{|c|c|c|c|c|c|}
\hline Host/sampling & Tick species & Nymph & Male & Female & Total number \\
\hline \multirow[t]{2}{*}{ Andean tapir } & Amblyomma multipunctum & 2 & 45 & 24 & 71 \\
\hline & Amblyomma spp. & & $4^{*}$ & & 4 \\
\hline \multirow[t]{3}{*}{ Cattle } & Rhipicephalus microplus & $6^{*}$ & $16^{*}$ & $38^{*}$ & 60 \\
\hline & Ixodes spp. & & & $5^{*}$ & 5 \\
\hline & Ixodes boliviensis & & & $1^{*}$ & 1 \\
\hline Vegetation & A. multipunctum & $10^{*}$ & $9^{* *}$ & $1^{*}$ & 20 \\
\hline
\end{tabular}

*Specimen deposited in the Museum of Zoology of Pontificia Universidad Católica from Ecuador.

spp., 60 R. microplus, 5 Ixodes spp. and 1 Ixodes boliviesis (Table 2).

\section{Detection and identification of tick-borne bacteria}

Tick-borne bacteria were tested for 151/161 specimens, excluding those deposited in the museum.

The presence of rickettsiae was screened by PCR assays targeting 2 fragments of the gltA rickettsial gene (1019 and $401 \mathrm{pb}$, respectively). Positive amplicons were obtained for $3 R$. microplus ( 2 male and 1 female specimens) removed from 2 cows from different farms. There were no differences in the sequences of $g l t A$ for amplicons derived from the DNA of the 3 rickettsial-infected $R$. microplus, and showed maximum identities (99.7\% -99.2\%) with glt $A$ gene from Rickettsia monacensis and Rickettsia tamurae as validated species (Table 3 ).

Subsequently, fragments of ompA (532 bp), ompB (420 bp), sca4 (928 bp), 16S rRNA gene (426 bp and $1500 \mathrm{bp}$, respectively), and $17 \mathrm{kDa}$-antigen gene (334 bp) were amplified to classify the Rickettsia at the species level.

The sequences of ompA (also identical each other) were closest to $R$. tamurae (95.9\% identity) and $R$. monacensis (95.7\% identity) (Table 3).

For $\operatorname{ompB}$, the DNA sequences of the 3 rickettsiaepositive $R$. microplus were identical to each other and showed $99.2 \%$ identity with $R$. monacensis and $97.1 \%$ identity with $R$. tamurae (Table 3 ).

Unfortunately, no amplicons were obtained in PCR assays targeting sca4 gene. Attempts to sequence the rickettsial 16S rRNA and pan-bacterial 16S rRNA amplicons for the $3 R$. microplus were inconclusive for Rickettsia.
Curiously, A. marginale was amplified in 1 out of these 3 specimens using pan-bacterial 16S rRNA primers (see below). In addition, the sequences of $17 \mathrm{kDa}$ antigen gene did not match with those available in GenBank.

In 2005, Raoult et al. established the criteria for the taxonomic classification of potential new Rickettsia species [32]. They proposed the 'Candidatus' status for a bacterium not established in pure culture that did not exhibit more than one of the following percentages of nucleotide identity: $>99.8,>99.9,>98.8,>99.2$, and $>99.3$ for $r r s$ (16S rRNA), gltA, ompA, ompB, and sca4, respectively, with a validated Rickettsia species. According to our results, only amplicons for the gltA, ompA, ompB and $17 \mathrm{KDa}$ were obtained. Therefore, based on the recommended nomenclature [32], a Candidatus status could not be assigned to this microorganism. We designated this bacterium as Rickettsia sp. 12G1.

The presence of Anaplasma spp. was detected in 15 out of 151 samples, including 2 A. multipunctum and 13 $R$. microplus. On the one hand, the partial sequences of msp 2 and 16S rRNA gene from Anaplasma spp. for $A$. multipunctum (a female tick from Andean tapir and a male tick from vegetation) and $8 R$. microplus (all female ticks from one cow) were, when available, closest (96.6$100 \%$ identity) to $A$. phagocytophilum (Table 4). On the other hand, the $16 \mathrm{~S}$ rRNA sequences (EHR and GEP regions) for $5 R$. microplus (3 female and 2 male specimens) removed from 3 cows in two farms, were respectively identical each other, and matched (100\% identity) with more than one Anaplasma species (assigned to A. marginale, Anaplasma ovis, A. phagocytophilum and Anaplasma centrale) for both PCR targets. Maximum identity with

Table 3 Maximum identities of rickettsial sequences detected in 3 Rhipicephalus microplus from Ecuador with validated Rickettsia species

\begin{tabular}{|c|c|c|c|c|}
\hline \multirow[t]{2}{*}{ Gene sequence } & \multicolumn{4}{|c|}{ \% identity with Rickettsia spp. (bp) } \\
\hline & R. monacensis & GenBank no. & R. tamurae & GenBank no. \\
\hline gltA [KF831358] & $99.5(625 / 628)$ & DQ100163 & $99.2(623 / 628)$ & AF394896 \\
\hline gltA (5' end) [KF831359] & $99.7(349 / 350)$ & DQ100163 & $99.4(348 / 350)$ & AF394896 \\
\hline ompA [KF831361] & $95.7(444 / 464)$ & DQ100169 & $95.9(445 / 464)$ & DQ103259 \\
\hline ompB [KF831360] & $99.2(379 / 382)$ & EF380356 & $97.1(371 / 382)$ & DQ113910 \\
\hline
\end{tabular}

bp: base pairs; [ ]: GenBank accession number generated in this study; GenBank no.: GenBank accession number; R.: Rickettsia. 
Table 4 Anaplasmataceae species detected in ticks from Ecuador

\begin{tabular}{|c|c|c|c|c|c|c|c|c|c|c|c|c|}
\hline \multirow[t]{3}{*}{ Bacterium (no.) } & \multirow{3}{*}{$\begin{array}{l}\text { Host/ } \\
\text { sampling }\end{array}$} & \multirow{3}{*}{$\begin{array}{l}\text { No. and stage } \\
\text { of tick species }\end{array}$} & \multicolumn{10}{|l|}{ Gene } \\
\hline & & & \multicolumn{2}{|l|}{$m s p 2$} & \multicolumn{2}{|l|}{ 16S rRNA } & \multicolumn{2}{|c|}{ 16S rRNA (EHR) } & \multicolumn{2}{|c|}{ 16S rRNA (GEP) } & \multicolumn{2}{|c|}{ Pan-bacterial 16S rRNA } \\
\hline & & & $\begin{array}{l}\text { Maximum \% } \\
\text { identity (bp) }\end{array}$ & $\begin{array}{l}\text { GenBank } \\
\text { acc. no. }\end{array}$ & $\begin{array}{l}\text { Maximum \% } \\
\text { identity (bp) }\end{array}$ & $\begin{array}{l}\text { GenBank } \\
\text { acc. no. }\end{array}$ & $\begin{array}{l}\text { Maximum \% } \\
\text { identity (bp) }\end{array}$ & $\begin{array}{l}\text { GenBank } \\
\text { acc. no. }\end{array}$ & $\begin{array}{l}\text { Maximum \% } \\
\text { identity (bp) }\end{array}$ & $\begin{array}{l}\text { GenBank } \\
\text { acc. no. }\end{array}$ & $\begin{array}{l}\text { Maximum \% } \\
\text { identity (bp) }\end{array}$ & $\begin{array}{l}\text { GenBank } \\
\text { acc. no. }\end{array}$ \\
\hline \multirow{7}{*}{$\begin{array}{l}\text { A. phagocytophilum } \\
\text { or closely related } \\
\text { genotypes (10) }\end{array}$} & Tapir & 1F A. multipunctum & $99.3(290 / 292)$ & CP000235 & ND & & ND & & ND & & NP & \\
\hline & Farm 1, Cow 1 & 3F R. microplus & $\begin{array}{l}96.6-98.3 \\
(280-285 / 290)\end{array}$ & FJ600595 & ND & & ND & & ND & & NP & \\
\hline & & $2 F$ R. microplus & $97.9(284 / 290)$ & CP000235 & ND & & ND & & ND & & NP & \\
\hline & & 1F R. microplus & $96.6(282 / 292)$ & AY164493 & $100(497 / 497)$ & JF893938 & ND & & ND & & NP & \\
\hline & & 1F R. microplus & $96.5(278 / 288)$ & AY164493 & ND & & ND & & ND & & NP & \\
\hline & & 1F R. microplus & $96.9(281 / 290)$ & FJ600595 & $100(497 / 497)$ & JF893938 & ND & & ND & & NP & \\
\hline & Vegetation & $1 \mathrm{M}$ A. multipunctum & $99.3(289 / 291)$ & AY626255 & ND & & ND & & ND & & NP & \\
\hline \multirow[t]{8}{*}{ A. marginale (2) } & Farm 1, Cow 2 & 1F R. microplus & ND & & ND & & $100(305 / 305)$ & СР001079 & $100(297 / 297)$ & СР001079 & $100(1129 / 1129)$ & СР000030 \\
\hline & & & & & & & & JN558818 & & JN558818 & & \\
\hline & & & & & & & & DQ648489 & & EU436153 & & \\
\hline & & & & & & & & СР001759 & & & & \\
\hline & Farm 1, Cow 3 & 1F R. microplus & ND & & ND & & $100(305 / 305)$ & СР001079 & $100(297 / 297)$ & СР001079 & $100(1129 / 1129)$ & CP000030 \\
\hline & & & & & & & & JN558818 & & JN558818 & & \\
\hline & & & & & & & & DQ648489 & & EU436153 & & \\
\hline & & & & & & & & СР001759 & & & & \\
\hline \multirow[t]{11}{*}{ Anaplasma spp. (3) } & Farm 1, Cow 2 & $1 \mathrm{M}$ R. microplus & ND & & ND & & $100(305 / 305)$ & СР001079 & ND & & $99.4(1222 / 1229)$ & JQ480818* \\
\hline & & & & & & & & JN558818 & & & & \\
\hline & & & & & & & & DQ648489 & & & & \\
\hline & & & & & & & & CР001759 & & & & \\
\hline & Farm 1, Cow 3 & $1 \mathrm{M}$ R. microplus & ND & & ND & & $100(305 / 305)$ & СР001079 & $100(297 / 297)$ & СР001079 & $99.4(1222 / 1229)$ & JQ480818* \\
\hline & & & & & & & & JN558818 & & JN558818 & & \\
\hline & & & & & & & & DQ648489 & & EU436153 & & \\
\hline & & & & & & & & СР001759 & & & & \\
\hline & Farm 2, Cow 1 & 1F R. microplus & ND & & ND & & ND & & $100(297 / 297)$ & СР001079 & $99.4(1222 / 1229)$ & JQ480818* \\
\hline & & & & & & & & & & JN558818 & & \\
\hline & & & & & & & & & & EU436153 & & \\
\hline
\end{tabular}

*Coxiella endosymbiont of Rhipicephalus turanicus isolate DGGE.

A. phagocytophilum: Anaplasma phagocytophilum; A. multipunctum: Amblyomma multipunctum; A. marginale: Anaplasma marginale; R.: Rhipicephalus; M: male; F: Female; ND: Not detected; NP: Not performed;

CP001079-CP000030: Anaplasma marginale sequences from GenBank; JN558818: Anaplasma ovis sequence from GenBank; DQ648489-EU436153: Anaplasma phagocytophilum sequences from GenBank; CP001759:

Anaplasma centrale sequence from GenBank. 
validated species of Ehrlichia genus did not exceed 95\% with any of these 16S rRNA target genes (Table 4). Since these fragment genes were highly conserved for these species, in an attempt to identify the Anaplasma species, DNA extracts of these 5 samples were used as templates of pan-bacterial $16 \mathrm{~S}$ rRNA PCR assays. The sequences corresponding to 2 out of $5 \mathrm{R}$. microplus were identical to each other and homologous ( $100 \%$ identity) to A. marginale. In these 2 cases, percentages of identity were 99.6, 99.5 and $97.2 \%$ when compared to A. ovis, A. centrale and human pathogenic $A$. phagocytophilum, respectively. Sequencing results for the 3 remaining ticks matched (99.4\% identity) with a Coxiella endosymbiont of Rhipicephalus turanicus (GenBank accession no. J480818) (Table 4).

Table 5 summarizes the detection rates for Rickettsia spp. and Anaplasma spp. Ehrlichia species were not amplified in any of the 151 ticks analyzed in this study. Lastly, B. burgdorferi s.l. was not detected in any ticks when flaB gene and 5S-23S rRNA intergenic spacer region were tested by PCR.

\section{Co-infections}

Out of 18 positive ticks, one of them (5.6\%) was found co-infected with 2 bacteria. The co-infection detected was A. marginale with Rickettsia sp. $12 \mathrm{G} 1$ in one $R$. microplus tick collected from a cow.

\section{GenBank accession numbers}

Sequences obtained in this study have been deposited in the GenBank database under the following accession numbers: KM077433-8 (identification of ticks) and KF831358-62 (rickettsial genes).

\section{Discussion}

A total of 161 ticks (nymphs or adult specimens) removed from Andean tapirs, cattle and vegetation, and belonging to Amblyomma, Rhipicephalus and Ixodes genera, was included in the present study. These tick genera had been previously reported to occur in Ecuador
$[3,33,34]$. Based on morphological and genetic criteria, arthropods were classified as 91 A. multipunctum, 4 Amblyomma spp., $60 \mathrm{R}$. microplus, 5 Ixodes spp. and 1 I. boliviesis. On the one hand, A. multipunctum was collected from vegetation and found attached to Andean tapirs. This tick species was originally described from a Tapirus sp. in North America, and it has been reported in Venezuela, Colombia and Ecuador [35,36]. Partial sequences of the mitochondrial 16S rRNA gene of A. multipunctum specimens from Ecuador had been previously generated [37]. Our group has completed this molecular description with sequences of the 12S rRNA fragment gene (GenBank accession no. KM077433). On the other hand, R. microplus and Ixodes spp. were removed from cows, as well as one specimen of I. boliviensis that was genetically characterized herein using mitochondrial 16S rRNA gene as PCR target (GenBank accession no. KM077437). $R$. microplus, known as the cattle tick, is widely distributed in cattle from tropical regions [3]. This is the first description of I. boliviensis in Ecuador, although it has been found in cattle from Costa Rica [38].

As far as we know, this is the first report where ticks from Ecuador were evaluated for the presence of Rickettsia spp., Anaplasma spp., Ehrlichia spp. and Borrelia spp.

The circulation of a potential Candidatus Rickettsia species (designated Rickettsia sp. 12G1) in R. microplus ticks removed from cattle in Ecuador is reported. According to our data, this novel Rickettsia was closest to $R$. monacensis and R. tamurae, as validated species. $R$. monacensis has been so far reported from Ixodes ricinus, and R. tamurae from Amblyomma testudinarium [39]. The human pathogenic role of $R$. monacensis was first reported in Spain [18], and one case of $R$. tamurae infection has been detected in Japan [40]. Nevertheless, no evidence of human pathogenicity is presented herein for Rickettsia sp. 12G1, and there is no evidence to suggest that this Rickettsia is transmissible to humans. Other new genotypes with unknown pathogenicity that also belong to the same lineage of $R$. tamurae and $R$. monacensis, such as

Table 5 Detection rates for Rickettsia spp. and Anaplasma spp.

\begin{tabular}{llllll}
\hline Host/sampling & Tick species & \multicolumn{2}{l}{ Detection rate\% (number of infected ticks/number of total ticks) } \\
\cline { 3 - 6 } & & Rickettsia spp. & A. phagocytophilum & A. marginale & Anaplasma spp. \\
\hline Andean tapir & A. multipunctum & 0 & $1.4(1 / 71)$ & 0 & 0 \\
Cattle & Amblyomma spp. & 0 & 0 & 0 & 0 \\
& R. microplus & $5.3(3 / 57)$ & $14.0(8 / 57)$ & $3.5(2 / 57)$ & $5.3(3 / 57)$ \\
Vegetation & Ixodes spp. & 0 & 0 & 0 & 0 \\
Total & A. muliviensis & 0 & 0 & 0 & 0 \\
\hline A. munctum & & $2(3 / 151)$ & $6.3(1 / 16)$ & $1.3(2 / 151)$ & $2(3 / 151)$ \\
\hline
\end{tabular}

A. phagocytophilum: Anaplasma phagocytophilum; A. marginale: Anaplasma marginale; A. multipunctum: Amblyomma multipunctum; R. microplus: Rhipicephalus microplus; I. boliviensis: Ixodes boliviensis. 
Rickettsia sp. strain Colombianensi or Rickettsia sp. strain IbR/CRC, have been documented in $R$. microplus or $I$. boliviensis from the New World $[41,42]$.

In our study, $A$. phagocytophilum or closely related genotypes have been detected in ticks removed from Andean tapirs, cows and vegetation. It is known that the high intraspecific variability observed in the $m s p 2$ gene of A. phagocytophilum promotes the adaptation of the bacterium to different hosts and could justify its distribution in various environments [43]. As expected, the $m s p 2$ sequences obtained in this study (corresponding to 10 ticks) showed high genetic variability. Whereas the $16 \mathrm{~S}$ rRNA sequences matched, when available $(\mathrm{n}=2)$, with A. phagocytophilum pathogenic for humans (GenBank accession no. CP000235), msp 2 sequences for 5 specimens (1 A. multipunctum from an Andean tapir and 4 R. microplus from cows) demonstrated relatedness with human pathogenic $A$. phagocytophilum but differed by $0.7-3.4 \%$ $[44,45]$. In addition, $m s p 2$ sequences obtained from $4 R$. microplus were closest (96.6-98.3\% identity) to $A$. phagocytophilum from Japanese Ixodes persulcatus [46]. Lastly, the msp2 sequence for $1 \mathrm{~A}$. multipunctum from vegetation was $99 \%$ identical to one $A$. phagocytophilum strain from rodents in Florida (also highly similar to human pathogenic reference strain) [47].

As far as we know, the occurrence of $A$. phagocytophilum or closely related genotypes had not been previously detected neither in Ecuador nor in ticks removed from tapirs. Nevertheless, A. phagocytophilum or closely related Anaplasma spp. have been found in blood samples from domestic (dogs and cats) and wild animals (deer) in Brazil [48-50]. This is the first evidence of A. phagocytophilum in $R$. microplus in the New World. Nevertheless, this bacterium had been previously found in $R$. microplus from China [51].

Based on the sequencing results of the 16S rRNA gene, $2 R$. microplus specimens removed from cows tested positive for $A$. marginale and 3 harbored Anaplasma spp. (assigned to A. marginale, A. ovis, A. phagocytophilum and $A$. centrale).

A. marginale, which is transmitted by $R$. microplus, has a worldwide occurrence and is considered as one of the most prevalent pathogens causing cattle morbidity and mortality in subtropical and tropical countries, including Latin America [52,53]. Our study evidences the first molecular detection of $A$. marginale in $R$. microplus from Ecuador. This bacterium had been previously detected in Ecuadorian blood samples from cattle by PCR [54] and also in R. microplus ticks in Philipinnes [55].

Moreover, no evidence of Ehrlichia spp. or B. burgdorferi s.l.-infected ticks has been found in Ecuador. Nevertheless, in South American countries, new members of the Ehrlichia genus and the B. burgdorferi s.l. complex have been recently described in Brazil, Uruguay and Chile [56-59].

\section{Conclusions}

In summary, this is the first description of Rickettsia sp. in ticks from Ecuador, and the analyses of sequences suggest the presence of a potential novel Rickettsia species. The complete characterization and distribution of the novel Rickettsia sp. 12G1, as well as its possible pathogenic role for animals and humans, needs to be determined.

Our data also showed that ticks from Andean tapirs, cattle and vegetation in Ecuador (Amblyomma and Rhipicephalus) were naturally infected with Anaplasmataceae and that co-infection (A. marginale and Rickettsia sp.) occurred.

\section{Competing interests}

The authors declare they have no competing interests.

\section{Authors' contributions}

Designed the study: JAO, AP. Collected and identified ticks: CP, AMP. Processed samples and analyzed sequences: CP, AMP. Analyzed the data: AP, AMP, JAO. Wrote the paper: AP, AMP, JAO. All authors read and approved the final version of the manuscript.

\section{Acknowledgements}

This study operated under the following permit from the government of Ecuador: N020-IC-FAU/FLO-DPN/MA, as well as appropriate export permits, as required.

We are grateful to the veterinary team from The Andean tapir conservation project' (EcoCiencia Foundation), and local farmers for their help with ticks collection.

We are also grateful to José M. Venzal (University of the Republic, Uruguay) and Valeria C. Onofrio (Instituto Butantan, Brazil) for their help with taxonomic identification of ticks.

We appreciate the support from Red Iberoamericana de Investigación y Control de Enfermedades Rickettsiales (RIICER, N²10RT0403), Programa Iberoamericano de Ciencia y Tecnologías para el Desarrollo (CYTED). This study was presented in part in the I Congreso Latinoamericano de Tapires y II Congreso Ecuatoriano de Mastozoología, Puyo, Pastaza (Ecuador), May 8-11, 2013 (oral communication I-CLT 048), and in the IV Congreso Latinoamericano de Enfermedades Rickettsiales, San José (Costa Rica), July 22-24, 2013 (abstracts A-17 and B-13).

Received: 12 July 2014 Accepted: 15 January 2015

Published online: 24 January 2015

\section{References}

1. Sonenshine DE, Lane RS, Nicholson WL. Ticks (Ixodida). In: Mullen G, Durden $L$, editors. Medical and Veterinary Entomology. New York: Academic Press; 2002. p. 517-58.

2. Guglielmone AA, Estrada-Peña A, Keirans JE, Robbins RG. Ticks (Acari: Ixodida) of the Neotropical Zoogeographic Region. Houten: Atalanta; 2003.

3. Barros-Battesti D, Arzua M, Bechara GH. Carrapatos de Importância Medico-Veterinaria da Região Neotropical: Um Guia llustrado para Identificação de Espécies. Sao Pablo: Vox/ICTTD-3/ Butantan; 2006.

4. Spolidorio MG, Andreoli GS, Martins TF, Brandão PE, Labruna MB. Rickettsial infection in ticks collected from road-killed wild animals in Rio de Janeiro, Brazil. J Med Entomol. 2012;49:1510-4.

5. André MR, Dumler JS, Scorpio DG, Teixeira RH, Allegretti SM, Machado RZ. Molecular detection of tick-borne bacterial agents in Brazilian and exotic captive carnivores. Ticks Tick Borne Dis. 2012;3:247-53.

6. Barbosa da Silva J, Vinhote WM, Oliveira CM, André MR, Machado RZ, DaFonseca $\mathrm{AH}$, et al. Molecular and serological prevalence of Anaplasma marginale in water buffaloes in northern Brazil. Ticks Tick Borne Dis. 2014:5:100-4.

7. Diaz AG, Castellanos A, Piñeda C, Downer C, Lizcano DJ, Constantino E, et al. Tapirus pinchaque. In: IUCN 2014. IUCN Red List of Threatened Species. Version 2014.1. 2008. http://www.iucnredlist.org/details/21473/0.

8. Labruna MB, Whitworth T, Bouyer DH, McBride J, Camargo LM, Camargo EP, et al. Rickettsia bellii and Rickettsia amblyommii in Amblyomma ticks from 
the State of Rondônia, Western Amazon, Brazil. J Med Entomol. 2004;41:1073-81.

9. Guglielmone AA, Beati L, Barros-Battesti DM, Labruna MB, Nava S, Venzal JM, et al. Ticks (Ixodidae) on humans in South America. Exp Appl Acarol. 2006;40:83-100.

10. Szabó MP, Pinter A, Labruna MB. Ecology, biology and distribution of spotted-fever tick vectors in Brazil. Front Cell Infect Microbiol. 2013;3:27.

11. Londoño AF, Díaz FJ, Valbuena G, Gazi M, Labruna MB, Hidalgo M, et al. Infection of Amblyomma ovale by Rickettsia sp. strain Atlantic rainforest, Colombia. Ticks Tick Borne Dis. 2014;5:672-5.

12. Fairchild GB, Kohls GM, Tipton VJ. The ticks of Panama (Acarina: Ixodoidea) In: Wenzel WR, Tipton VJ, editors. Ectoparasites of Panama. Chicago: Field Museum of Natural History; 1966. p. 167-219.

13. Jones EK, Clifford CM, Keirans JE, Kohls GM. The ticks of Venezuela (Acarina: Ixodoidea) with a key to the species of Amblyomma in the western hemisphere. Brigham Young University Science Bulletin, Biological Series. 1972;17:1-40.

14. Black WC, Piesman J. Phylogeny of hard- and soft-tick taxa (Acari: Ixodida) based on mitochondrial 16S rDNA sequences. Proc Natl Acad Sci U S A. 1994;91:10034-8.

15. Beati L, Keirans JE. Analysis of the systematic relationships among ticks of the genera Rhipicephalus and Boophilus (Acari: Ixodidae) based on mitochondrial 125 ribosomal DNA gene sequences and morphological characters. J Parasitol. 2001;87:32-48.

16. Zahler M, Gothe R, Rinder H. Genetic evidence against a morphologically suggestive conspecificity of Dermacentor reticulatus and Dermacentor marginatus (Acari: Ixodidae). Int J Parasitol. 1995;25:1413-9.

17. Weisburg WG, Barns SM, Pelletier DA, Lane DJ. 16S ribosomal DNA amplification for phylogenetic study. J Bacteriol. 1991;173:697-703.

18. Jado I, Oteo JA, Aldámiz M, Gil H, Escudero R, Ibarra V, et al. Rickettsia monacensis and human disease, Spain. Emerg Infect Dis. 2007;13:1405-7.

19. Labruna MB, Whitworth T, Horta MC, Bouyer DH, McBride JW, Pinter A, et al. Rickettsia species infecting Amblyomma cooperi ticks from an area in the state of São Paulo, Brazil, where Brazilian spotted fever is endemic. J Clin Microbiol. 2004:42:90-8.

20. Roux V, Fournier PE, Raoult D. Differentiation of spotted fever group rickettsiae by sequencing and analysis of restriction fragment length polymorphism of PCR-amplified DNA of the gene encoding the protein rOmpA. J Clin Microbiol. 1996;34:2058-65.

21. Regnery RL, Spruill CL, Plikaytis BD. Genotypic identification of rickettsiae and estimation of intraspecies sequence divergence for portions of two rickettsial genes. J Bacteriol. 1991;173:1576-89.

22. Choi YJ, Lee SH, Park KH, Koh YS, Lee KH, Baik HS, et al. Evaluation of PCR-based assay for diagnosis of spotted fever group rickettsiosis in human serum samples. Clin Vaccine Immunol. 2005;12:759-63.

23. Sekeyova Z, Roux V, Raoult D. Phylogeny of Rickettsia spp. inferred by comparing sequences of 'gene D', which encodes an intracytoplasmic protein. Int J Syst Evol Microbiol. 2001;51:1353-60.

24. Márquez FJ, Muniain MA, Soriguer RC, Izquierdo G, Rodríguez-Baño J, Borobio MV. Genotypic identification of an undescribed spotted fever group rickettsia in Ixodes ricinus from southwestern Spain. Am J Trop Med Hyg. 1998:58:570-7

25. Oliveira RP, Galvão MA, Mafra CL, Chamone CB, Calic SB, Silva SU, et al. Rickettsia felis in Ctenocephalides spp. fleas, Brazil. Emerg Infect Dis. 2002:8:317-9.

26. Zeidner NS, Burkot TR, Massung R, Nicholson WL, Dolan MC, Rutherford JS, et al. Transmission of the agent of human granulocytic ehrlichiosis by Ixodes spinipalpis ticks: evidence of an enzootic cycle of dual infection with Borrelia burgdorferi in Northern Colorado. J Infect Dis. 2000;182:616-9.

27. Massung R, Slater K, Owens JH, Nicholson WL, Mather TN, Solberg VB, et al. Nested PCR assay for detection of granulocytic ehrlichiae. J Clin Microbiol. 1998;36:1090-5.

28. Inokuma H, Raoult D, Brouqui P. Detection of Ehrlichia platys DNA in brown dog ticks (Rhipicephalus sanguineus) in Okinawa Island, Japan. J Clin Microbiol. 2000;38:4219-21.

29. Eddlestone SM, Diniz PP, Neer TM, Gaunt SD, Corstvet R, Cho D, et al. Doxycycline clearance of experimentally induced chronic Ehrlichia canis infection in dogs. J Vet Intern Med. 2007;21:1237-42.

30. Clark K, Hendricks A, Burge D. Molecular identification and analysis of Borrelia burgdorferi sensu lato in lizards in the southeastern United States. Appl Environ Microbiol. 2005;71:2616-25.
31. Rijpkema SG, Molkenboer MJ, Schouls LM, Jongejan F, Schellekens JF. Simultaneous detection and genotyping of three genomic groups of Borrelia burgdorferi sensu lato in Dutch Ixodes ricinus ticks by characterization of the amplified intergenic spacer region between $5 \mathrm{~S}$ and 235 rRNA genes. J Clin Microbiol. 1995;33:3091-5.

32. Raoult D, Fournier PE, Eremeeva M, Graves S, Kelly PJ, Oteo JA, et al Naming of Rickettsiae and rickettsial diseases. Ann N Y Acad Sci. 2005;1063:1-12.

33. Labruna MB, Guglienmone AA. Ticks of New World Tapirs. Tapir Conservation. 2009:18:21-8

34. Vásquez CL, Muro JJ, Clavijo JJ. Garrapatas del género Ixodes Latreille, 1795 y Rhipicephalus (Boophilus) Koch, 1844 (Acari: Ixodidae) presentes en la colección de Zoología Agrícola, Decanato de Agronomía, UCLA, Lara, Venezuela. Entomotropica. 2011;26:89-97.

35. Neumann LG. Révision de la famille des Ixodidés. Mémoires de la Société de Zoologie de France. 1899;12:211-7.

36. Voltzit OV. A review of Neotropical Amblyomma species (Acari: Ixodidae). Acarina. 2007;15:3-134.

37. Labruna MB, Martins TF, Nunes PH, Costa FB, Portero F, Venzal JM. New records of Amblyomma multipunctum and Amblyomma naponense from Ecuador, with description of A. multipunctum nymph. J Parasitol. 2013;99:973-7.

38. Alvarez V, Bonilla R, Chacón I. Relative abundance of Amblyomma spp. (Acari: Ixodidae) in bovines (Bos taurus and B. indicus) from Costa Rica. Rev Biol Trop. 2003;51:435-43.

39. Parola P, Paddock CD, Socolovschi C, Labruna MB, Mediannikov O, Kernif T, et al. Update on tick-borne rickettsioses around the world: a geographic approach. Clin Microbiol Rev. 2013;26:657-702.

40. Imaoka K, Kaneko S, Tabara K, Kusatake K, Morita E. The first human case of Rickettsia tamurae infection in Japan. Case Rep Dermatol. 2011;3:68-73.

41. Miranda J, Portillo A, Oteo JA, Mattar S. Rickettsia sp. strain Colombianensi (Rickettsiales: Rickettsiaceae): A New Proposed Rickettsia Detected in Amblyomma dissimile (Acari: Ixodidae) from iguanas and free-living larvae ticks from vegetation. J Med Entomol. 2012;49:960-5.

42. Troyo A, Moreira-Soto A, Carranza M, Calderón-Arguedas O, Hun L, Taylor L. Detection of an undescribed Rickettsia sp. in Ixodes boliviensis from Costa Rica. Ticks Tick Borne Dis. 2014;5:672-5.

43. Rymaszewska A. Variability within the msp2 gene in populations of Anaplasma phagocythopilum. Folia Biol (Praha). 2010;56:269-75.

44. Barbet AF, Meeus PF, Bélanger M, Bowie MV, Yi J, Lundgren AM, et al. Expression of multiple outer membrane protein sequence variants from a single genomic locus of Anaplasma phagocytophilum. Infect Immun. 2003:71:1706-18.

45. Lin M, Kikuchi T, Brewer HM, Norbeck AD, Rikihisa Y. Global proteomic analysis of two tick-borne emerging zoonotic agents: Anaplasma phagocytophilum and Ehrlichia chaffeensis. Front Microbiol. 2011;2:24

46. Wuritu, Ozawa Y, Gaowa, Kawamori F, Masuda T, Masuzawa T, et al. Structural analysis of a p44/msp2 expression site of Anaplasma phagocytophilum in naturally infected ticks in Japan. J Med Microbiol. 2009;58:1638-44.

47. Clark KL. Anaplasma phagocytophilum in small mammals and ticks in northeast Florida. J Vector Ecol. 2012;37:262-8.

48. Santos HA, Pires MS, Vilela JA, Santos TM, Faccini JL, Baldani CD, et al. Detection of Anaplasma phagocytophilum in Brazilian dogs by real-time polymerase chain reaction. J Vet Diagn Invest. 2011;23:770-4.

49. Sacchi AB, Duarte JM, André MR, Machado RZ. Prevalence and molecular characterization of Anaplasmataceae agents in free-ranging Brazilian marsh deer (Blastocerus dichotomus). Comp Immunol Microbiol Infect Dis. 2012;35:325-34.

50. André MR, Baccarim Denardi NC, de Sousa KC M, Gonçalves LR, Henrique PC, Grosse Rossi Ontivero CR, et al. Arthropod-borne pathogens circulating in free-roaming domestic cats in a zoo environment in Brazil. Ticks Tick Borne Dis 2014. 2014;5:545-51.

51. Zhang L, Liu H, Xu B, Lu Q, Li L, Chang L, et al. Anaplasma phagocytophilum infection in domestic animals in ten provinces/cities of China. Am J Trop Med Hyg. 2012:87:185-9.

52. Vidotto O, Barbosa CS, Andrade GM, Machado RZ, Da Rocha MA, Silva SS Evaluation of a frozen trivalent attenuated vaccine against babesiosis and anaplasmosis in Brazil. Ann N Y Acad Sci. 1998;849:420-3.

53. Kocan KM, de la Fuente J, Blouin EF, Coetzee JF, Ewing SA. The natural history of Anaplasma marginale. Vet Parasitol. 2010;167:95-107. 
54. Soto KK. Determinación de la prevalencia de anaplasmosis en el ganado bovino faenado en la empresa metropolitana de Rastro de Quito (EMRQ) mediante la aplicación de las técnicas de diagnóstico: microscopía de frotis sanguíneos, reacción en cadena de la polimerasa (PCR) y ensayo inmunoenzimático competitivo (CELISA). In: PhD thesis. Sangolquí: Escuela Politécnica del Ejército; 2010.

55. Ybañez AP, Sivakumar T, Ybañez RH, Ratilla JC, Perez ZO, Gabotero SR, et al. First molecular characterization of Anaplasma marginale in cattle and Rhipicephalus (Boophilus) microplus ticks in Cebu, Philippines. J Vet Med Sci. 2013;75:27-36.

56. Cabezas-Cruz A, Vancová M, Zweygarth E, Ribeiro MF, Grubhoffer L, Passos LM. Ultrastructure of Ehrlichia mineirensis, a new member of the Ehrlichia genus. Vet Microbiol. 2013;167:455-8.

57. Zweygarth E, Schöl H, Lis K, Cabezas-Cruz A, Thiel C, Silaghi C, et al. In vitro culture of a novel genotype of Ehrlichia sp. from Brazil. Transbound Emerg Dis. 2013;60:86-92.

58. Barbieri AM, Venzal JM, Marcili A, Almeida AP, Gonzalez EM, Labruna MB. Borrelia burgdorferi sensu lato infecting ticks of the Ixodes ricinus complex in Uruguay: first report for the Southern Hemisphere. Vector Borne Zoonotic Dis. 2013;13:147-53.

59. Ivanova LB, Tomova A, González-Acuña D, Murúa R, Moreno CX, Hernández $C$, et al. Borrelia chilensis, a new member of the Borrelia burgdorferi sensu lato complex that extends the range of this genospecies in the Southern Hemisphere. Environ Microbiol. 2014;16:1069-80.

\section{Submit your next manuscript to BioMed Central and take full advantage of:}

- Convenient online submission

- Thorough peer review

- No space constraints or color figure charges

- Immediate publication on acceptance

- Inclusion in PubMed, CAS, Scopus and Google Scholar

- Research which is freely available for redistribution 